\title{
En dynamisk kulturarv - Dybbøls 12 metamorfoser
}

INGE ADRIANSEN*

Title: A dynamic cultural heritage - the twelve metamorphoses of Dybbøl. Abstract: Dybbol is the brow of a hill located about $30 \mathrm{~km}$ north-east of the border between Denmark and Germany. This area was once the former Danish Duchy of Schleswig, which was under German rule in the period from 1864 to 1920. Dybbol was also the site of intense fighting during the Schleswig-Holstein Revolt of 1848-50 and the Danish-German War of 1864. There are remains of both Danish and German fortifications and earthworks, along with large mass graves in which troops from Denmark, Schleswig-Holstein and Germany lie buried.

After a plebiscite about the placing of the border was held in 1920, Schleswig was divided up, and the northern part - which included Dybbol - became part of Denmark. This was followed by a comprehensive "Danishification" of the cultural landscape, which had previously been dominated by a large Prussian victory monument and numerous German memorial stones. A Danish national park was set up at Dybbol in 1924, with the backing of the local population and financial support from a national collection appeal, and formally opened by the Danish prime minister.

After this, Dybbol became the epitome of the institutionalised cultural heritage of the state of Denmark, and would almost certainly be included in any "cultural canon" of the most significant geographical locations that have helped shape the Danish sense of national identity.

However, Dybbol also features another - less comfortable - aspect of the Danish cultural heritage, bearing witness to Danish acts of vandalism perpetrated against the German monuments found here. Any study of the use of the history associated with Dybbol uncovers layer upon layer of episodes that speak of conflicting interests and countless metamorphoses that led to the site being imbued with new values and a sequence of new identities.

And in step with the resurgence of nationalist sentiments in Denmark since the mid-1980s, there has been a corresponding, strengthened re-annexation of the cultural heritage associated with Dybbøl. The need to cling on to and retain established, familiar positions and a fundamental sense of belonging are well-known aspects of the process of globalisation, and are seen throughout the world. In Dybbol, this deep-felt need has resulted in the construction of a Danish fortification, and the Danish flag flying atop the many flagpoles has become more frequent sight. 
This process can also be interpreted as an expression of Danish foreign policy taking on a more active role in the world.

Key words: Nationalism, canon, identity, cultural heritage, metamorphosis, memorial site, national symbol, battlefield, policy of remembrance.

Dybbøl betegner et højdedrag, en landsby, en slagmark og en erindringspolitisk lokalitet af første rang - både for danske og tyske. Desuden er Dybbøl et kulturarvsareal med rester af såvel en dansk som en tysk befæstning med skanser og med en gravlund med fire store massegrave med 360 faldne danske og tyske soldater samt enkelte fra de nordiske lande. Her ligger også et af de velkendte danske nationale symboler - møllen, der blev "tvende gange skudt i grus" under de to slesvigske krige i midten af 1800-tallet. På Dybbøl Banke blev der i 1924 oprettet en såkaldt nationalpark med opbakning fra lokalbefolkningen, finansieret med midler fra en landsindsamling og indviet af statsminister Stauning. Dybbøl er således indbegrebet af den institutionaliserede og kanoniserede kulturarv og ville givetvis komme med på en kanon med de 10 mest betydningsladede steder i Danmark. ${ }^{1}$

Kanon, kulturarv og konsensus - det er nært forbundne begreber. Det gælder i høj grad for Dybbøl, hvor stedets betydning som metafor for dansk identitet og fællesskab synes at være hævet over al diskussion. Dette fremgår blandt andet af brugen af Dybbøl Mølle med vajende Dannebrog som illustration på den danske stats officielle hjemmeside "Hvad er indfødsret?". ${ }^{2}$ Der er ingen forklarende billedtekst, så Dybbøl formodes at være kendt af alle, også af de kommende nye statsborgere, som hjemmesiden er skrevet for. Dybbøl fremstår her som et eksempel på dansk kulturarv, som indfødsretten sikrer adgang til, en indlysende og bekvem kulturarv, hvorom der er fuld konsensus. I tråd hermed har historiebrugen af dette erindringssted især fokuseret på den nationale nostalgi, men det rummer også en ubekvem kulturarv, der fortæller om et omfattende dansk hærværk. For Dybbøl er ikke blot et erindringssted for dansksindede sønderjyder og rigsdanskere, men også for tysksindede sønderjyder og rigstyskere. Der er således knyttet meget forskelligartede identiteter til dette sted. ${ }^{3}$

Når man går i gang med at undersøge den historiebrug, der er foregået her - og fortsat gør det - så afdækkes lag på lag af historier, der vidner om alternative forsøg på identitetsskabelse, modstridende interesser og en hel række metamorfoser. Frem til 1840'erne var Dybbøl kun betegnelsen på et højdedrag med en vindmølle og den lille landsby på højdedragets vestside, hvorfra det i slutningen af 1700tallet var blevet udskiftet fem gårde, der blev flyttet ud på østsiden af banken ned mod Sønderborg. Dybbøl ligger på den jyske halvø tæt på øen Als og har god strategisk beliggenhed. Derfor blev der kæmpet i dette område både under borgerkrigen 1848-1850 og under den dansk-tyske krig i 1864. Den sidste krig endte med afståelse af begge hertugdømmer, Slesvig og Holsten. Det betød, at Dybbøl blev en del af kongeriget Preussen og fra 1871 også en del af det tyske kejserrige.

I de første årtier efter 1864 anså preusserne Dybbøl for at have strategisk betydning. Derfor blev der på ruinerne af de sønderskudte danske skanser opført tyske skanser, der indgik i Festung Sonderburg-Düppel og bestod af 
to armerede skanserækker, henholdsvis på Sundeved og på Als. Men i 1880'erne var det tyske kejserrige blevet så stærkt, at man ikke længere frygtede et dansk angreb. Festung Sonderburg-Düppel blev derfor nedlagt, kun jordvoldene efter det tyske skanseanlæg lå tilbage. Efter det tyske nederlag i Første Verdenskrig kom der en række folkeafstemninger i grænseområder med nationalt blandede befolkninger. Det skete også i det nordlige Slesvig, hvor hovedparten af befolkningen havde fastholdt en dansk identitet gennem mere end et halvt århundredes tysk styre. $75 \%$ af den sønderjyske befolkning stemte for indlemmelse i Danmark, og i overensstemmelse hermed blev den nye grænse draget i 1920 .

Denne statspolitiske udvikling er baggrunden for en hel række omdannelser af Dybbøl med tilskrivning af nye værdier og identiteter. Der er sket ved, at der hele tiden er føjet nye lag på, og undertiden bryder gamle lag op til overfladen igen, så Dybbøl nogle gange kan reflektere meget forskellige værdier og fortolkninger af fortiden. Historien om disse talrige forvandlinger, der her fremlægges, viser, at kulturarv og værdikamp er nært forbundet. $^{4}$

1. OMDANNELSE - FRA KORNMARKER TIL SLAGMARK OG ERINDRINGSSTED 1848-50

Indtil midten af 1800-tallet var Dybbøl Banke en lokalitet som talrige andre: Godt bakket moræneland dækket af græs- og kornmarker og med nogle få gårde og en mølle. Men da der i revolutionsåret 1848 udbrød en borgerkrig i den dansk-tyske helstat, sædvanligvis kaldet Treårskrigen, kom Dybbøl pludselig til at spille en vigtig rolle. Et oprør var brudt i Kiel, og fæstningen i Rendsborg i det sydligste Slesvig blev overtaget ved et kup. Hovedpar- ten af mandskabet tilsluttede sig oprørerne, der krævede selvstændighed for de to hertugdømmer Slesvig og Holsten. Denne revolutionære rejsning blev støttet af tropper fra det tyske forbund, og det meste af Slesvig blev nu besat, før den danske hær nåede frem. I Dybb$ø$ l sogn var der indkvartering med tyske tropper på de fleste gårde, men 28. maj 1848 gik den danske hær over Alssund, erobrede Dybb$ø$ l Banke og drev de fjendtlige tropper et par kilometer tilbage. Et kraftigt tysk modangreb blev afværget den 5. juni, og i det næste årstid stod der tyske tropper i den vestlige del af Dybbøl sogn og danske tropper i den østlige del. Kampen den 5. juni, hvor det tyske modstød blev afvist, blev fejret som en stor dansk sejr - og det var også den eneste sejr, der var værd at nævne i det første krigsår. I 1849 stod der et nyt slag på Dybbøl Banke den 13. april. En tysk styrke beskød området med 28 kanoner, og Dybbøl Mølle brændte ned. Kampen endte uafgjort, og derefter var der ikke flere kamphandlinger i området før krigens afslutning ved udgangen af $1850 .^{5}$

Dybbøl-slaget 1848 var hurtigt blevet kendt gennem historiemalerier, træsnit og litografier, og datoen blev hurtigt til nationaldag, fordi den nye grundlov blev underskrevet af kongen netop på denne dato. I 1851, den første årsdag efter krigens ophør, blev der på Dybbøl Banke afholdt en stor fest til minde og tak for sejren i 1848 . Den blev gentaget i langt større stil i 1861 med deltagelse af civile og militære myndigheder, og dagen afsluttedes med festfyrværkeri og raketter fra orlogsskibe i Sønderborg havn. Arrangørerne lovede at gentage festen hvert tredje år, og de 6.000 deltagere kunne skilles med forventningen om at mødes på Dybbøl i juni 1864. Hermed var lokaliteten Dybbøl trådt ind i historien som et sted, hvor store begivenheder har udspillet sig. ${ }^{6}$ 
2. OMDANNELSE - ET LANDBRUGSOMRÅDE BLIVER TIL EN DANSK BEFÆSTNING 1861-64

Kort tid efter 5. junifesten i 1861 begyndte det danske militær at anlægge skanser på Dybbøl Banke. Dybbøl Banke havde under Treårskrigen vist sig at være forholdsvis let at forsvare og velegnet til fægtning, fordi man herfra kunne trække sig hurtigt og sikkert tilbage til Als. Da en ny krig truede i horisonten i 1861, blev det besluttet at anlægge det danske hovedforsvar ved Danevirke i det sydligste Slesvig, suppleret med flankebefæstninger ved Dybbøl og Fredericia.

I gårde og huse på Dybbøl Banke hørte man med stor bekymring om det planlagte skansebyggeri. Ingen havde lyst til at bo på glaciset $\mathrm{i}$ en kommende kampzone, men der lød beroligende ord fra myndighederne om den forebyggende virkning, som de nye forsvarsværker ville have på eventuelle angribere. Rigsdagen havde vedtaget en bevilling på 800.000 rigsdaler til opførelse af Dybbøl Skanser, men heraf var der ved krigens udbrud i 1864 kun anvendt ca. 113.000, og det rakte kun til ti åbne forsvarsværker, som skulle være forbundet med løbegrave, men endnu slet ikke var færdigbyggede. ${ }^{7}$ Det er et af de store paradokser i dansk historie, at regeringen førte en udfordrende udenrigspolitik i 1863 ved at

Dybbols 3. metamorfose: den danske befestning bliver til en slagmark. Her ses skanse 4, fotograferet den 19. april 1864, dagen efter erobringen, hvor sejrherrerne poserede for fotograf Brandt fra Flensborg. Foto: Museum Sønderjylland Sønderborg Slot.

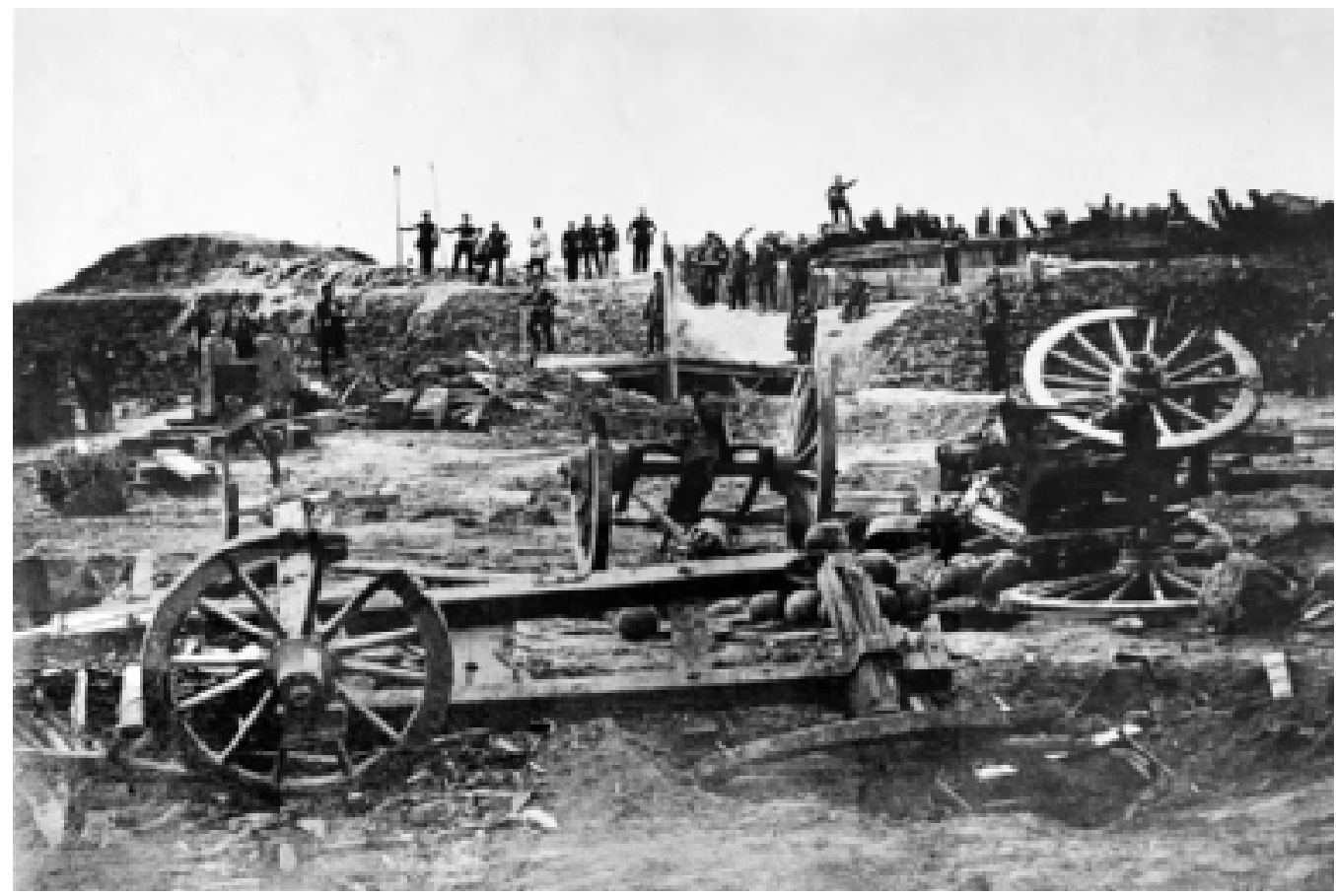


bryde internationale aftaler - og samtidigt forsømte at forberede landet militært på de repressalier, der måtte forventes. Men i befolkningen rådede en udbredt forestilling om de stærke forsvarsanlæg ved Danevirke og Dybbøl: Det skulle nok gå lige så som i juni 1848, og denne gang havde man jo rigtige skanser til de danske tropper.

\section{OMDANNELSE - DYBBøL BLIVER TIL EN DANSK-TYSK SLAGMARK I 1864}

Da krigen begyndte 1 . februar 1864, stod størstedelen af den danske hær ved Danevirke, men efter få dages kamp besluttede den danske overkommando at rømme stillingen, da den var for let at omgå. Tilbagetrækningen fra Danevirke skete 5.-6. februar i storm, sne og isslag. Da soldaterne ankom til Dybbøl 7. februar, opdagede de til deres dybe skuffelse, at forsvarsanlægget slet ikke var bygget færdigt. De tyske tropper kunne have indtaget Dybbølstillingen straks, hvis den tyske efterretningstjeneste havde fungeret tilfredsstillende. Herved ville mange tyske og endnu flere danske liv være sparet. Men også de tyske generaler troede på Dybbøl-befæstningens styrke og havde indstillet sig på en langvarig belejring.

Fra slutningen af februar til den 18. april var Dybbølstillingen under belejring. På skrænten ved Gammelmark på Broagerland og i området vest for skansernes søndre fløj blev der opstillet i alt 102 preussiske kanoner, som kunne beskyde de første seks danske skanser. De daglange bombardementer herfra ødelagde hele sydvestsiden af Dybbøl Banke. Landsbyen Dybbøl lå lidt mere beskyttet, cirka $1,5 \mathrm{~km}$ mod nordvest, men også den ramtes hårdt. Før stormdagen var mere end hvert andet hus og gård bombeskadet eller beskudt. Befolkningen var flygtet til Als eller længere ud på Sundeved. Næsten alle huse og gårde i

Dybbøl nedbrændte eller blev skudt i grus, for Dybbøl Mølle skete det 10. april.

Ved stormen på Dybbøl 18. april blev de danske skanser rendt over ende, og efter hårde kampe omkring møllen blev de danske tropper drevet tilbage til Als. Forsøget på at fastholde stillingen på trods af alle odds kom til at koste den danske hær ca. 1.700 døde, sårede og savnede samt hen ved 3.000 fanger - foruden en afgørende ødelæggelse af Dybbøl Skanser og Dybbøl Banke. Det tyske tab ved stormen var ca. 1.200 døde og sårede. Da mange soldater døde efter nogen tid på lazarettet, kan det præcise forhold mellem døde og sårede ikke opgives. ${ }^{8}$ Fredsforhandlinger blev indledt i London en uge senere. Trods ihærdig indsats fra neutrale stater blev der ikke opnået noget kompromis mellem de krigsførende parter. Da våbenhvilen udløb i juni, begyndte krigen derfor igen. De tyske tropper satte den 29. juni over Alssund fra Sandbjerg til Arnkil. Samme dag erobredes Als, og med dette andet danske nederlag var krigen afgjort. Fredsaftalen blev knusende for den danske helstat, som blev reduceret med $1 / 3$ af sit areal og 2/5 af befolkningen. Ud af ruinerne på Dybbøl opstod den danske nationalstat. Den flerkulturelle og flersprogede helstat var gået til grunde.

\section{OMDANNELSE - FRA DANSK BEF/ESTNING TIL TYSK BEFÆSTNING 1865-1884}

Også efter 1864 blev Dybbøl anset for at have strategisk betydning. Ruinerne af det danske skanseanlæg blev sløjfet, og på dets plads blev der allerede i 1865 påbegyndt et langt større tysk befæstningsanlæg, Festung SonderburgDüppel. I modsætning til Dybbøl Skanser blev denne befæstning færdigbygget. Den var 
stærkt armeret og bestod af to skanserækker på Sundeved og én på Als. I begyndelsen af 1880 'erne blev det imidlertid klart, at det nye stærke tyske kejserrige ikke behøvede at frygte et dansk forsøg på at generobre Slesvig. Dybbøl Banke havde mistet sin strategiske betydning. I 1884 blev Festung Sonderburg-Düppel nedlagt, mandskab og fæstningsskyts blev flyttet østpå, og kun de store jordvolde fra befæstningen lå tilbage i kulturlandskabet. ${ }^{9}$ Men navnet Düppel var fortsat kendt i Det Tyske Kejserrige, og kampene i 1864 hørte med til den obligatoriske historie, der blev indlært i skolerne.

\section{OMDANNELSE - FRA ET NEDERLAGSSYM- BOL TIL SYMBOL PÅ DANSK TAPPERHED OG TROFASTHED}

Det var kampen 18. april, som gjorde Dybbøl til et heroisk begreb i bevidstheden hos mange danskere. Fra et militærstrategisk synspunkt var det udtryk for en fejlbedømmelse at fastholde Dybbølstillingen til den bitre ende. Herom var den samtidige vurdering ens på dansk og tysk side. Men begge parter havde hurtigt fortrængt det irrationelle i kampen, der havde krævet unødvendigt mange ofre. I stedet for skete der en omtolkning og en heroisering af stormen på Dybbøl generelt og en mytologisering af nogle enkelte episoder og krigsdeltagere. ${ }^{10}$

I tiden under tysk styre var der mange rigsdanske, som besøgte Dybbøl Banke. Det var for at vandre i skanseområdet og besøge det mest fremtrædende danske mindesmærke: Dybbøl Mølle. Møllerparret, Jørgen Hansen og hans hustru, havde som de sidste civile forladt Dybbøl Banke 17. marts 1864. Efter krigen var de vendt tilbage til deres sønderskudte ejendom, som de lod genopføre. Dybbøl Møl- le, der var "tvende Gange skudt i Grus, atter rejst som Møllehus”, blev nu et symbol på den ukuelige danskhed i Sønderjylland. Medvirkende til at give møllen en særlig position som dansk national symbol var en rejseskildring af Holger Drachmann, Derovre fra Gransen, udgivet i 1877. Drachmann sidestiller her det tyske sejrsmonument Düppel Denkmal og Dybbøl Mølle som nationale monumenter og slår til lyd for, at møllen indgår i danske skolebøger ligesom Düppel Denkmal gjorde det i tyske skolebøger. Han foreslår direkte den danske skolekommission at gengive et træsnit af møllen i historiebøgerne ledsaget af et vers, hvori han hæver Dybbøl Mølle op i nationalsymbolikkens sfære:

Her staar jeg og vil ikke flytte min Fod som Vagt paa den vældige Banke;

Granater skal ikke rokke min Rod, og Ild ikke kvæle min Tanke.

Min Rod den munder i Danmarks Bund.

Min Tanke er den: der skal komme en Stund, hvor Hjerter omkring mig skal banke

om kap med det Hjerte af Egerod, som Mølleren sætte i Vingen lod;

Og slaa med sin Vinge og staa, hvor man stod, Med Ære og Ret; det er Tingen!"1

Efter Drachmann har andre danske forsøgt at skildre Dybbøl Mølle som symbol på danskheden, men ingen har nået hans retoriske højder eller føjet noget til hans fortolkninger. Dybbøl Mølle og Dybbøl Banke var trods nederlaget blevet synonyme med en stærk forsvarsvilje og en ukuelig danskhed.

Der udvikledes imidlertid også en anden "Dybbøl-lære" i Danmark. Det var den såkaldte sårfeber fra Dybbøl, det vil sige bevidstheden om at være en småstat, der er henvist til at agere på det udenrigspolitiske felt uden 
at have ydre magtmidler og være tvunget til at klare balancegangen mellem stormagternes alliancesystemer. Den meget forsigtige udenrigspolitik, som blev resultatet af denne erkendelse, fik i begyndelsen af 1900-tallet den negative betegnelse "Tyskerkursen”. Dens fortalere havde således en særdeles uheroisk tolkning af Dybbøl-læren, men denne tolkning kom ikke til synligt udtryk i kulturlandskabet og mindesmærkerne. ${ }^{12}$

\section{OMDANNELSE - DYBBØL BLIVER OGSÅ ET TYSK ERINDRINGSSTED}

Efter stormdagen blev Dybbøl også et tysk nationalt symbol, et udtryk for deutsche Treue und Tapferkeit. Det var af helt afgørende betydning for de tyske tropper, at der blev kæmpet den 18. april. En belejring, som var endt med en dansk tilbagetrækning og dermed overgivelse af Dybbølstillingen til modstanderne uden kamp, ville være opfattet som forsmædelig for den preussiske hær, fordi tysk blod ikke var blevet udgydt. På Dybbøl Banke blev der fra 1865 rejst mindesten over faldne preussere. Det var næsten udelukkende officerer, der blev hyldet med disse sten.

Düppel-Denkmal, et mindesmærke på 22 meters højde udført i sandsten i kejsertidens karakteristiske nygotik blev i 1872 indviet på toppen af Dybbøl Banke. Dette sejrmindesmærke med hyldest til den preussiske hær og konge var i høj grad med til at gøre Dybbøl Banke til et yndet mål for tyske turister. De store massegrave på bakkekammen, hvor mange af de faldne på stormdagen blev jordfæstet, understregede stedets betydning som tysk slagmark. Et nyt hotel, Düppelhöh, blev opført ved landevejen lige over for det tyske sejrsmonument. Værten arrangerede omvisninger i skanserne og forhandlede "historiske souvenirs". Der var omkring to kilometer at vandre fra centrum af Sønderborg til toppen af Dybbøl Banke, og de talrige mindesten var sammen med hotellet, kroer og kaffestuer undervejs medvirkende til at gøre Dybbøl Banke til en turistattraktion $i$ slutningen af 1800-årene.

Vejen fra nationalisme til turisme er sjældent lang - og tilbagevejen oftest kortere! Kulminationen som tysk erindringssted blev nået i 1914 ved 50-års-jubilæet for sejren i 1864,

Dybbols 6. metamorfose: Det $24 \mathrm{~m}$ hoje tyske sejrsmonument i nygotik kronede fra 1872 toppen af Dybbol Banke. Det afspejlede, at her var et tysk erindringssted, og at Dybbol var et symbol på preussisk tapperhed og kampvilje. Foto Museum Sonderjylland - Sonderborg Slot.

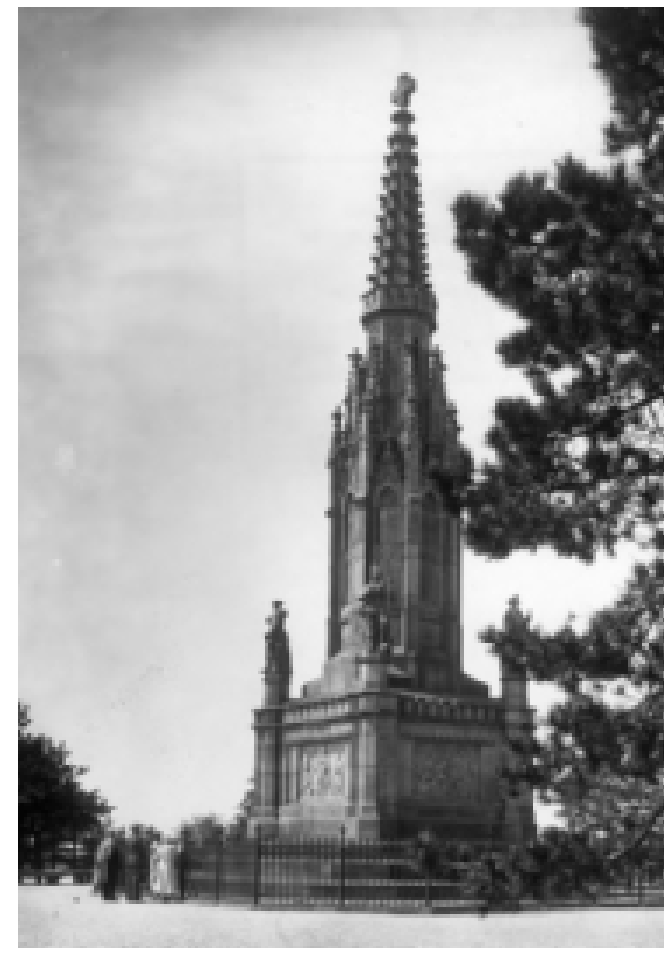




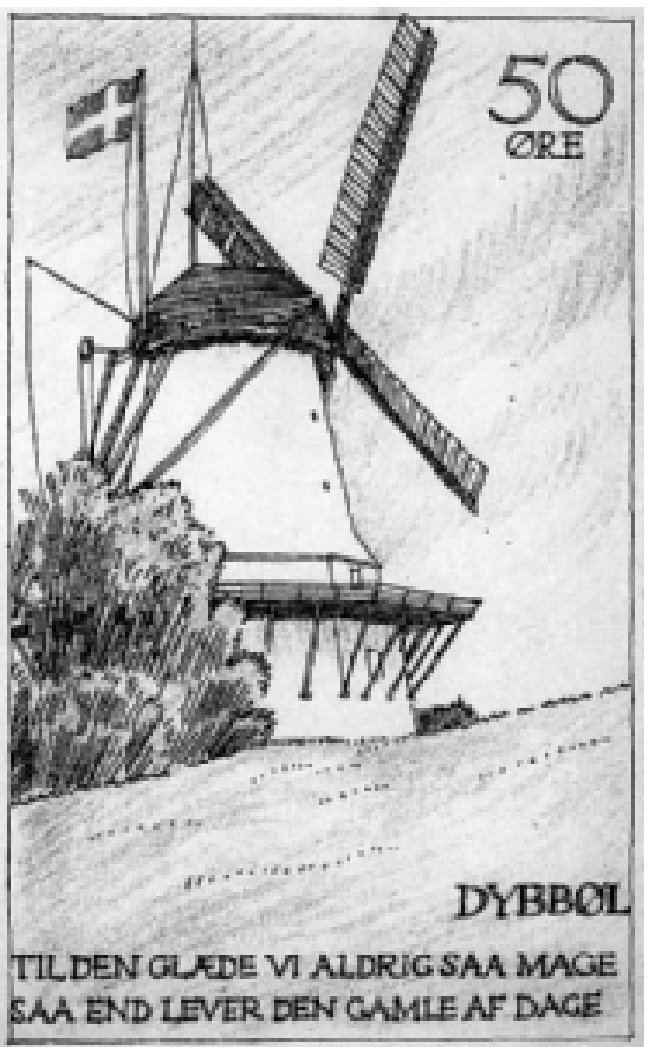

Dybbols 7. metamorfose: Dybbøl bliver indbegrebet af det serligt danske. Efter Forste Verdenskrig var der stor mangel pà skillemønt, og mange kommuner lod trykke egne pengesedler. I Dybbøl blev 50-ore-sedlen prydet med Dybbol Mølle med et vajende dannebrog og et Grundtvig-citat. Foto Museum Sønderjylland-Sønderborg Slot.

hvor der blev føjet et nyt lag til Dybbøl som tysk erindringssted, denne gang ikke som sejrsplads, men som festplads for hele nationen fra kejserfamilien til menigmand. Der blev afholdt to store mindefester på Dybbøl henholdsvis på stormdagen 18. april og 29. juni på dagen for de tyske troppers overgang til Als i 1864 og dermed den endelige erobring af hele hertugdømmet Slesvig. Den første fest var for lokalbefolkningen, mens den anden var for alle tyskere, og den foregik i den største af de tyske skanser på Dybbøl Banke. Der deltog omkring 2.000 krigsveteraner sammen med repræsentanter fra kejserfamilien, regeringen, hæren og flåden. Kejser Wilhelm var forhindret $\mathrm{i}$ at komme, men blev repræsenteret af sin bror, prins Heinrich, og i sin tale til veteranerne lovede han $\mathrm{dem}$ at fastholde Dybbøl og Slesvig under tysk styre. En anden taler fremdrog en såkaldt Dybbøl-morale:

Af Dybbølkæmperne har vi lært, at det ikke er modløshed, som fører til sejr, men alene den gamle preussiske tro på, at Preussens konger altid sejrer, og alle vegne fastholder sejren. Dette være sagt til dem, der altid har hånden udstrakt efter vort land og intet har lært af Dybbøl. ${ }^{13}$

Under festlighederne i skanserne indløb der et telegram til prins Heinrich om straks at rejse tilbage til Berlin. En udenrigspolitisk krise var under opsejling, da den østrigske kronprins var blevet skudt af en bosnisk serber dagen før, 28. juni. Skuddet i Sarajevo gav således genlyd ved den sidste store tyske manifestation på Dybbøl Banke.

\section{OMDANNELSE - DEN TYSKE BEFÆESTNING BLIVER DANSK FESTPLADS I 1920}

Skuddet i Sarajevo udløste en verdenskrig, der først sluttede 4 1/4 år senere med et tysk nederlag. Ved våbenstilstanden havde Tyskland accepteret, at dets grænser skulle reguleres på grundlag af princippet om folkenes selvbestemmelsesret. Dette nye statsdannende princip blev også anvendt i Nordslesvig efter anmodning fra de dansksindede sønderjyders re- 
præsentant i den tyske rigsdag. Ved en folkeafstemning 10. februar 1920 stemte $75 \%$ af befolkningen i det nuværende Sønderjylland for en indlemmelse i Danmark, og i Dybbøl var der over $90 \%$ danske stemmer. Genforeningen fandt sted som en løbende proces over nogle måneder i forsommeren 1920 og den 11 . juli 1920 blev den officielle genforeningsfest afholdt. Det foregik ikke på det traditionsrige mødested Skamlingsbanken og heller ikke i området omkring Dybbøl Mølle, men derimod i netop den tyske skanse, hvor sejrsfesten havde fundet sted kun seks år tidligere.

Ved at afholde den danske fest netop her blev der tilføjet et lag mere til Dybbøl som erindringssted, et lag, som danskerne - i lighed med tyskerne i 1914 - ønskede skulle fremstå som det endelige og afsluttende. Det blev udtrykt meget klart af hovedtaleren, grev Schack, der først omtalte den tyske jubilæumsfest og verdenskrigen og fortsatte:

Da Kanontordenen forstummede, sang Dybbøllærken atter over Vangen, og saa dansk er dette Land og Folk hernede, at vi til Trods for det vidunderlige, vi oplever, føler, at vort Møde her paa Dybbøl er ligesaa naturligt som den Fugls Kvidren, der står for os som symbol paa det danske Folkesind. Skal der fejres et Møde paa dette Sted, da maa det være et Møde som vort i Dag, hvor dansk møder dansk for ikke at skilles igen. ${ }^{14}$

Den danske nationale identitet bliver her gjort til natur og fremstår her som en egenskab organisk forbundet med landskabet. Ud fra en forestillingsverden om identiteter som naturprodukter - og som ikke kulturprodukter, som det jo er tilfældet - er kulturlandskabet på Dybbøl blevet omkalfatret i de næste 80 år, så det er blevet mere og mere "dansk". Allerførst blev den tyske skanse omdøbt til "Kon- geskansen", og hermed forsvandt hurtigt erindringen om, at den var en central del af et stort tysk befæstningsanlæg.

\section{OMDANNELSE - KULTURLANDSKABET FOR- DANSKES 1920-1945}

Fordanskningen af landskabet begyndte allerede før genforeningsfesten. Den preussiske stat havde i januar 1920 forsøgt at afhændede Düppel Denkmal til en privat forening, dannet med det formål at pleje de to sejrsmonumenter på Dybbøl og Arnkil. Da det var forbudt at sælge tysk statsejendom i afstemningsperioden blev dette ikke til noget. Til gengæld blev det foreslået fra dansk side, at de to monumenter kunne nedtages og transporteres syd for den nye grænse med henblik på en genopstilling i Tyskland. Til gengæld ville man fra dansk side gerne have udleveret Istedløven, der i 1864 var blevet fjernet fra kirkegården i Flensborg. Dette forslag om gensidig udveksling af den nationale kulturarv blev aldrig til noget, da man fra tysk side ikke ville gå i forhandling herom. ${ }^{15}$ Det tyske præg på Dybbøl kunne ikke uden videre fjernes, men det kunne modereres med et styrket dansk præg.

Det er baggrunden for, at fremtrædende sønderjyder arbejdede i 1919-20 for at få P.V. Jensen-Klints planlagte Grundtvig- monument, der endnu var under projektering, placeret på Dybbøl Banke i stedet for Bispebjerg Bakke! ${ }^{16}$ Denne store plan om den ultimative fordanskning af kulturlandskabet på Dybbøl kunne dog ikke gennemføres, men mange fandt, at noget måtte gøres for at sætte et nyt dansk præg på dette erindringssted og for at markere magtskiftet i 1920. Man enedes om at sikre området, hvor de gamle danske skanser havde ligget i tiden 1861-1864. De var en- 
ten skudt i ruiner i 1864 eller blot blevet jævnet med jorden efter krigen. På tomten var der enten sået græs eller rejst nye tyske skanser. Der var således ikke noget at se i selve terrænet, men stedet, grundvolden, burde sikres imod nyere byggeri, og en stor landsindsamling blev sat i gang i 1922. For at alle kunne være med i den opgave, blev der solgt "aktiebreve" på blot 1 krone til investering $\mathrm{i}$ en kommende "Nationalparken Dybbøl".

To år senere kunne nationalparken indvies. Den var skabt med midler dels fra landsindsamlingen, dels fra Carlsbergfondet, og den omfattede et område på 16 hektar. Omkredsen af de danske skanser var markeret med hvide cementbånd i terrænet, så de kunne træde frem for det indre blik. Den nye statsminister, Th. Stauning, foretog den officielle indvielse og understregede, at Dybbøl Nationalpark ikke kun var et begreb, der appellerede til folk af nationalkonservativ observans. Han understregede, at han modtog området både på regeringens og statens vegne og lovede at stedet ville blive bevaret som "Folkets Ejendom". Stauning udtalte også, at Nationalparken Dybbøl i højere grad skulle være et minde om den civile end om den militære kamp. Hans indvielsestale var et udtryk for et forsøg på at formulere en socialdemokratisk holdning til den symboltyngede Dybbøl Banke. Som regeringsbærende parti måtte Socialdemokratiet i gang med at afklare sit forhold til den nationale symbolik, og der blev arbejdet ihærdigt med dette tema i mange sammenhænge. ${ }^{17}$

I midten af 1920 'erne gik en lokalkomite i gang med at opsætte mindesten over faldne danske officerer, og i løbet af de næste par årtier blev Dybbøl Banke forsynet med flere hundrede mindesmærker af denne type. Det var upolerede natursten, især i granit, der blev rejst på højkant og forsynet med en kort indskrift i versaler. De var med til at sætte et nyt præg på landskabet og erindre de besøgende om dansk forsvarsvilje over for presset sydfra og kampens pris i de to krige Der var en markant social skævhed i denne ihærdige mindesmærkerejsning, idet den næsten udelukkende fortæller om faldne officerer og underofficerer. For den almindelige turist i området kan det virke besynderligt, at der tilsyneladende ikke faldt menige soldater i kampene på Dybbøl.

De nordiske frivillige i de to Slesvigske Krige blev hyldet med en mindestøtte, der blev rejst i oktober 1936. Ved afsløringen talte både Stauning og hærchefen, general Erik With. Statsministerens tale var noget varmere $i$ tonen end ved indvielsen af Nationalparken i 1924, og det skyldtes, at den udenrigspolitiske situation var blevet grundlæggende forandret. Naboen var ikke længere Weimar-Tyskland, men Det Tredje Rige, og til stede ved afsløringen var der repræsentanter fra det tyske mindretal, som højlydt krævede grænserevision, efter at Saarland året før havde stemt sig tilbage til Tyskland. Derfor indeholdt Staunings tale et klart budskab om, at "mange af Nationens mest dyrebare Minder" var knyttet til Dybbøl, og at debat om 1920-grænsen var et for længst overstået stadium.

Men der lurede andre farer end tyske revanchister. Den stigende urbanisering sneg sig ind på Nationalparken, og den var ved at tabe sin værdi på grund af moderne byggeri alt for tæt på. Det var en sag, som bekymrede danske arkitekter, og en gruppe bestående af C.Th. Sørensen, Dan Fink og billedhuggeren Jens Lund udarbejdede et forslag til en fuldstændig fredning af Dybbøl. Det byggede på den opfattelse, at skanseområdet var en helligdom for tyske som for danske, men at den nuværende tilstand var uskøn, og at området burde samles 
til en landskabelig enhed. De fremlagde derfor et detaljeret forslag til en markant ændring af hele banken øst for skanserækken mod Sønderborg. Der skulle anlægges af en voldgade, indrettes en mødeplads med et amfiteater og opføres et krigsmindesmærke med en karakter, som bevirkede, at både danske og tyske skulle kunne samles ved det. ${ }^{18}$

Forslaget blev offentliggjort i juli 1940, men tiden var ikke velegnet til at fremme det - hverken på det bevidsthedsmæssige eller økonomiske plan. Den gennemarbejdede plan blev da også pure afvist både af rigsmyndighederne og lokalbefolkningen. Dybbøl skulle fortsat være erindringssted med et klart og entydigt dansk fortegn, og der skulle ikke ændres i særlig grad på anlægget - og slet ikke opføres fælles mindesmærker. De tyske levn i landskabet blev kun tålt, fordi det jo ikke kunne være anderledes.

Det kunne det imidlertid efter befrielsen i 1945. Natten mellem 12. og 13. maj lød der et mægtigt brag fra Dybbøl Banke - Düppel Denkmal var sprængt i luften og lå helt ruiner! Gerningsmændene blev aldrig fundet, men da de havde anvendt meget dynamit, er det rimeligt at antage, at det var danske modstandsfolk, som havde udøvet hærværket. Et statsligt udvalg blev nedsat, og i en betænkning et år senere frarådede dette udvalg en genopførelse af monumentet. Et enkelt relief fra monumentet var nogenlunde bevaret og kom på

Dybbols 8. metamorfose: Kulturlandskabet fordanskes fra 1920-1940, og denne udvikling kulminerede med sprangningen af det tyske sejrmonument $i$ 13. maj 1945. Egnens befolkning valfartede til besigtigelse af ruinerne i de naste uger. Foto Museum Sønderjylland - Sonderborg Slot

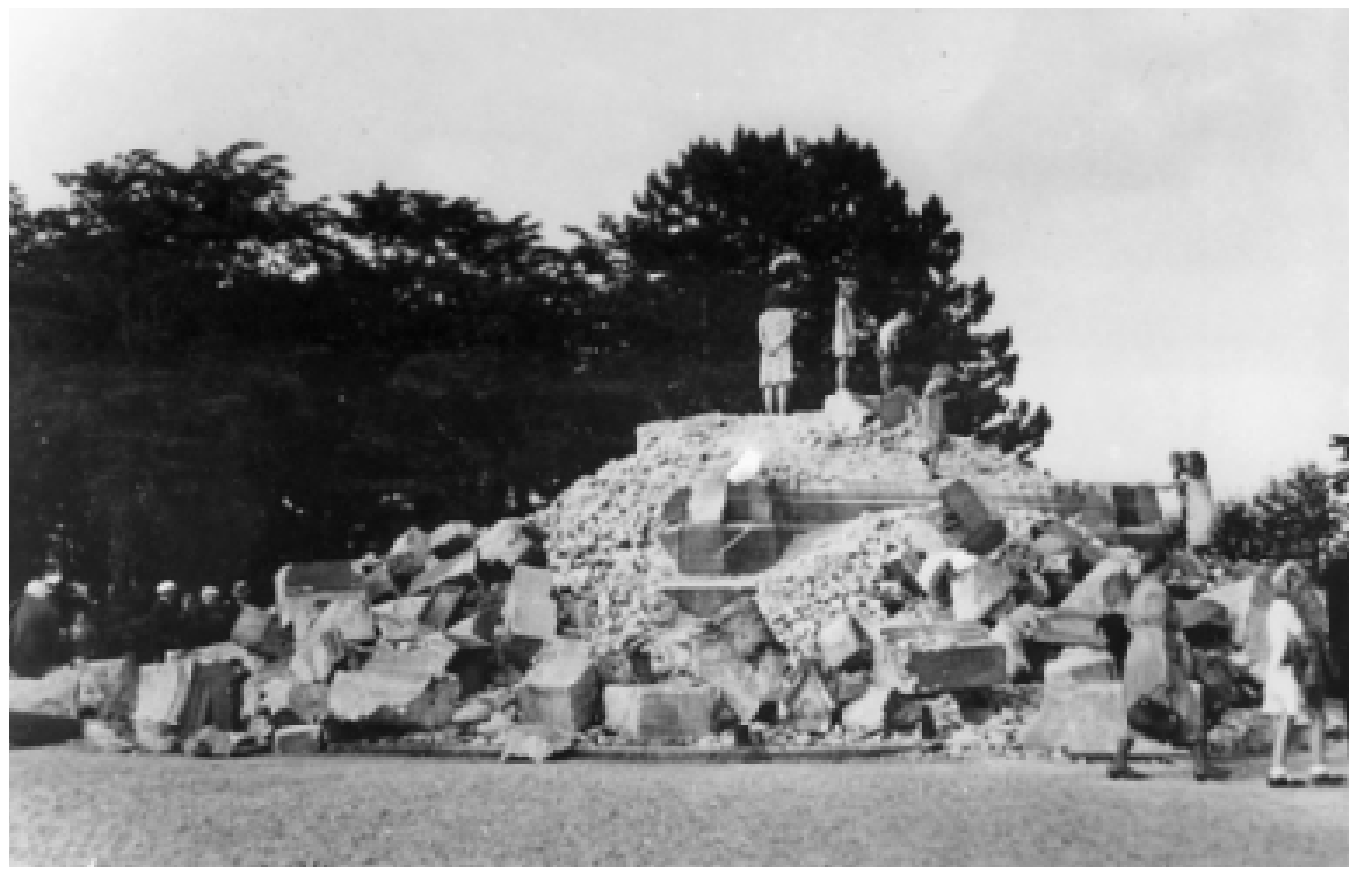


Sønderborg Slot. Alle andre dele blev sænket i en grusgrav på banken - nederst monumentresterne, dernæst murbrokker og øverst jord og muld. For at hindre opgravning blev der tinglyst et forbud mod genopgravning. ${ }^{19} \mathrm{Mo}-$ numentet havde delvis stået på fundamentet til det danske blokhus i Skanse 4. Dette fundament blev nu helt afdækket, og herved blev den tyske monumentplads forvandlet til en dansk skansetomt. Det danske præg på Dybb$ø$ l var nu det helt dominerende.

\section{OMDANNELSE - GLEMSEL S/ENKER SIG OVER DE NATIONALE MINDER}

I 1964 blev 100-års-dagen for stormen på Dybbøl markeret med en dansk mindefest uden deltagelse fra den tyske forbundsstat, selvom Danmark og Tyskland havde været militære partnere i NATO siden 1955. Det mest bemærkelsesværdige ved mindedagen var, at kong Frederik 9. helt uventet bad om ordet og holdt en brandtale, hvori han hyldede forsvarsvilje og fædrelandskærlighed. ${ }^{20}$ Kongens tale var rettet mod de tendenser til historieløshed, som han så i tiden. Og i en vis udstrækning tolkede han tidens tegn rigtigt. Fra omkring 1960 var en vis grad af glemsel begyndt at sænke sig over nationale mødesteder som Dybbøl. De traditionelle skoleudflugter med børn, der klassevis vandrede fra banegården til banken med skolens fane i spidsen, forsvandt på nogle få år i tiden omkring 1960. Tiden var løbet fra at se på møllen udefra og lege "to mand frem for en enke" i skanserne efter at have spist madpakke og drukket den medbragte sodavand for til sidst at trænges om en af de mange souvenirboder.

Ikke blot skoleudflugterne også den almindelige turiststrøm svandt ind. Danskerne drog på busrejser i Europa, og danske sevær-

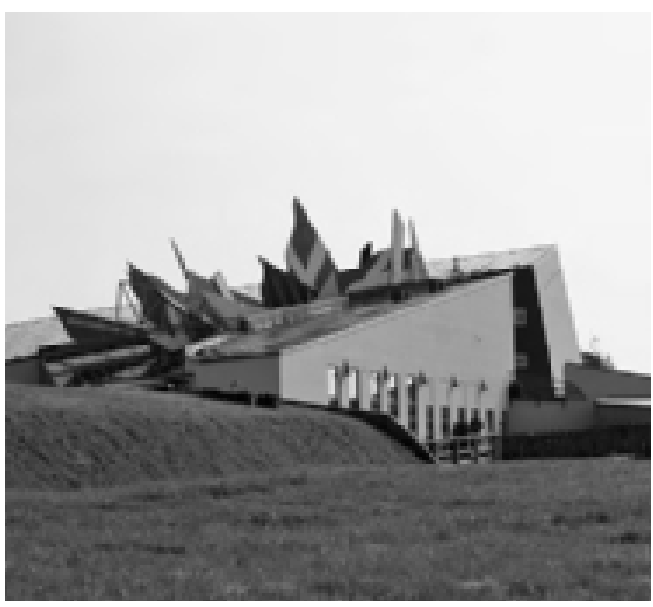

Dybbøls 9. metamorfose: Historiecenter 1992 som et udtryk for en fornyet dansk nationalisme. Centeret er tegnet af arkitekterne Ernst Lohse og Wilhelm Freddie i 1990. De vandt 1. promie i en arkitektkonkurrence om centeret og beskrev bygningen således: "Som et nationalt minde valder den op afjorden., et minde om krigens gru - et ragnarok, da Danmark blev løbet over endemen samtidigt et vidnesbyrd om mod, styrke og vilje til at overleve." Foto Museum Sønderjylland-Sønderborg Slot.

digheder havde ikke længere samme tiltrækningskraft. Denne udvikling kunne også følges syd for grænsen, og turiststrømmen herfra blev mærkbart reduceret på få år. Kun i de ældre tyske generationer var der endnu lidt interesse for Dybbøl som slagmark og dets betydning som et væsentligt trin på vejen, der førte til den tyske samling i 1871. For unge tyskere - som for unge danskere - kunne Dybbøl henlægges på historiens pulterkammer. De to verdenskrige, ikke mindst den sidste, skyggede ganske over de slesvigske krige. Denne udvikling er ikke forbavsende, og den rejser et grundlæggende spørgsmål om, hvilken værdi erindringssteder har i sig selv, og om de kan og bør fastholdes, hvis ingen i nutiden 
finder dem meningsfulde, interessante eller perspektiverende?

\section{OMDANNELSE - NATIONAL OPRUSTNING FRA 1988 OG OPRETTELSE AF HISTORIECENTERET}

I løbet af 1980'erne kom der en ny interesse for de nationale begreber, ikke blot på europæisk, men på globalt plan. Den nye nationale bølge kunne synes paradoksal, da nationalisme og nationalstatsbegrebet gennem et par årtier havde været i tilsyneladende tilbagegang, og af mange forskere var dømt til helt at forsvinde. ${ }^{21}$ At dette var en overfladisk fortolkning af udviklingen, fremgår af antallet af nationalstater. Det blev tredoblet fra 1945 til 1985, og væksten fortsatte med øget styrke. ${ }^{22}$ Nynationalismen var særlig iøjefaldende på Balkan, men også på Dybbøl Banke mærkedes virkningerne af denne ideologi. Der blev iværksat statslige opkøb af gårdene på Dybbøl Banke, og i 1989 i 125-året for nederlaget, blev den danske skanse 4 frilagt. Der blev opstillet 2 store fæstningskanoner og skiltningen af skanseområdet blev forbedret.

Dette var dog kun forspillet til en langt større investering i formidlingen af den historie, som er knyttet til stedet: Opførelsen af Historiecenter Dybbøl Banke, der skulle have formidlingen af Dybbøl Banke og 1864-krigen som sin hovedopgave. Initiativtagerne var den nyoprettede Fonden Dybbøl Banke, hvor Sønderjyllands amtsborgmester var formand og Sønderborgs borgmester næstformand. Også Miljøministeriet var repræsenteret i fondens bestyrelse, så det var ikke overraskende, at denne bestyrelse formåede at udvirke de nødvendige dispensationer til opførelse af et omfattende byggeri i det fredede område ganske tæt på nationalparken Dybbøl Banke. Det bør dog bemærkes, at grundstykket fra det höh) indgik i det nye byggeri. Det blev muliggjort ved et samvirke mellem en privat fond, amt og kommune. ${ }^{23}$ I alt var der ved åbningen i 1992 investeret omkring 40 mio. kr. i denne formidling af Dybbøl Banke.

Da amtsborgmester Kresten Philipsen i 1990 tog det første spadestik til centeret, udtalte han, at Dybbøl var "det sted, hvor vi tabte Danmarkshistoriens flotteste nederlag". ${ }^{24}$ Den forestilling om dansk martialsk heroisme, der ligger bag dette bemærkelsesværdige udsagn, blev understøttet både af bygningens arkitektur og den oprindelige indretning af historiecenteret med en fokusering på de mest heroiske dele af krigen i 1864.

Denne fokusering på Dybbøl som nationalt symbol kulminerede i 1999, hvor der over hele landet blev afholdt fester $i$ anledning af grundlovens 150-års-jubilæum. Dansk Folkeparti havde valgt at afholde deres grundlovsfest på Dybbøl Banke, fordi det med partiets ord var "selve symbolet på Danmark og danskheden", og dette udsagn blev udbygget i talerne af Pia Kjærsgaard og Søren Krarup..$^{25}$ Mødet tiltrak stor opmærksomhed og mange protester mod partiets "snævre definition på det at være dansk", som Naser Khader udtrykte det. Ingen anfægtede derimod, at Dybbøl var et centralt dansk erindringssted, og derfor satte Dansk Folkepartis brug af netop dette sted også sindene i kog. ${ }^{26}$

I 1999 fremlagde centeret en omfattende udbygningsplan, som var budgetteret til yderligere 39 mio. kr. I planen indgik en opførelse af dele af en dansk skanse, et "børnenes Dybbøl" med legeplads og skydebane, en konfliktsal, der aktualiserede 1864-krigen med paralleller til nutidige krige, og en apsissal til eftertanke og refleksion. Forslaget udløste en betydelig debat og 
68 kritik i hele landsdelen, og enden på denne sidste kamp om Dybbøl blev en beslutning om kun at realisere skansebyggeriet. ${ }^{27}$

\section{OMDANNELSE - FRA ET MONOKULTURELT TIL ET FLERKULTURELT ERINDRINGSSTED I 2001}

Fra 1920 har man hvert år 18. april kunnet opleve to kransenedlæggelser: Om formiddagen var der en officiel dansk ceremoni med

Dybbols 11. metamorfose: Den falles dansk-tysk kransenedlaggelse fra 2001 er et udtryk for, at Dybbol nu officielt anerkendes som et erindringssted for flere nationer. Foto Museum Sønderjylland - Sønderborg Slot.

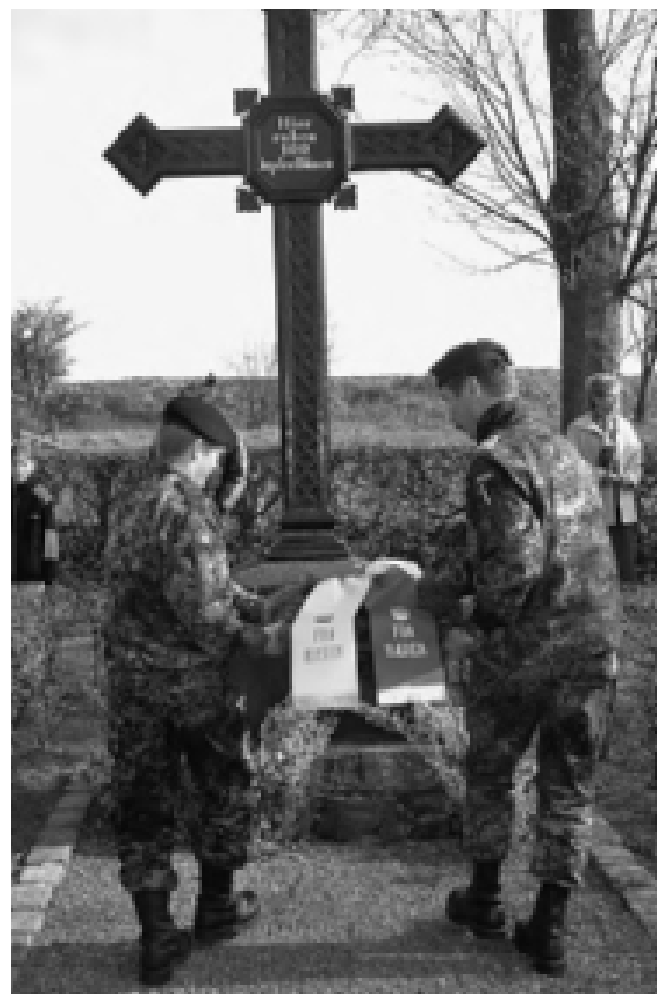

militære og civile myndigheder samt skoleelever og mange tilskuere. Senere på dagen var der en halvofficiel tysk kransenedlæggelse med repræsentanter fra det tyske mindretals ledelse og lokale medlemmer, men ikke officielle repræsentanter fra Tyskland. Den danske ceremoni forestås af garnisonskommandanten i Sønderborg, og denne valgte i 2001 at indbyde repræsentanter fra den tyske hær til at deltage i kransenedlæggelsen. Det skulle fortsat være en dansk ceremoni, men nu altså med tyske gæster. Det udløste debat og protester, og folketingsmedlem Søren Krarup, der er valgt i Sønderborgkredsen, rettede en forespørgsel til forsvarsministeren om garnisonskommandantens initiativ. ${ }^{28}$ I sit svar bakkede ministeren op bag initiativet, men tilsyneladende uden større entusiasme. De næste to-tre år var der kun få protester i forbindelse med kransenedlæggelsen 18. april, og fra 2006 synes de fleste at have accepteret, at den nationale mindedag på Dybbøl er blevet mere åben. Medvirkende hertil kan være presseomtalen af fejringen af 60-årsdagen for d-dag, de allieredes landgang i Normandiet i 1944. Temaet for markeringen var "forsoning", og den tyske forbundskansler var en af hovedtalerne. Når franskmænd og englænderne kumme markere denne dag sammen med modstanderne, var det svært at argumentere for, at Dybbøldagen til minde om en kamp 140 år tidligere skulle markeres med adskilte ceremonier.

I takt med denne ændring på Dybbøl er der opstået flere og flere lokalt prægede ceremonier med kransenedlæggelser på lokaliteter med mindesten for 1848-50, 1864, og 1940-45. Hvorvidt der er nogen forbindelse mellem de to fænomener, er det for tidligt at vurdere endnu, men begge viser, hvorledes forskellige vi-samhørigheder iscenesættes, justeres og styrkes. 
12. OMDANNELSE - DANSK RE-TERRITORIALISERING

Bestyrelsen for Fonden Dybbøl Banke besluttede efter den nævnte debat og kritik i 2000 kun at iværksætte den første del af de omstridte udbygningsplaner med opførelse af en dansk skanse. Til gengæld erkendte man, at seriøs historieformidling ikke kan hvile økonomisk i sig selv, og derfor besluttedes efterfølgende, at centeret skulle indgå i samdrift med Sønderborg Slot. Udbygningen med rekonstruktion af en del af en dansk skanse blev indviet i 2007.. ${ }^{29}$ Der er anlagt en del af en dansk skanse med et stort blokhus, to krudtmagasiner og en rullebro. Desuden er her placeret en såkaldt soldaterby med fem feltbarakker, der er ramme om formidling af danske soldaters vilkår bag fronten. Det sker gennem forskellige former for 're-enactments' og 'levendegørelse af historien' i form af de besøgendes deltagelse i madlavning, brevskrivning til hjemmet og lignende.

Der er tale om en formindsket skanserekonstruktion, der vender mod øst og ikke mod vest, som de danske skanser gjorde, og den er udstyret med flere bygninger, end det var tilfældet i 1864, for soldaterbyen måtte af pladsmæssige grunde placeres inde i selve skanserekonstruktionen. Derved er stedets autenticitet uvægerligt blevet svækket, men til gengæld er Dybbøls værdi som formidlingscenter og turistattraktion blevet forøget, og det afspejler sig da også i et øget besøgstal efter udbygningen.

I en kulturarvssammenhæng er det væsentligste dog, at det danske præg på Dybbøl Banke herved er blevet yderligere styrket. Der er sket en re-territorialisering, og i sin tale ved indvielsen i sommeren 2007 var undervisningsminister Bertel Haarder indirekte inde på dette aspekt, da han så centeret som et ud-

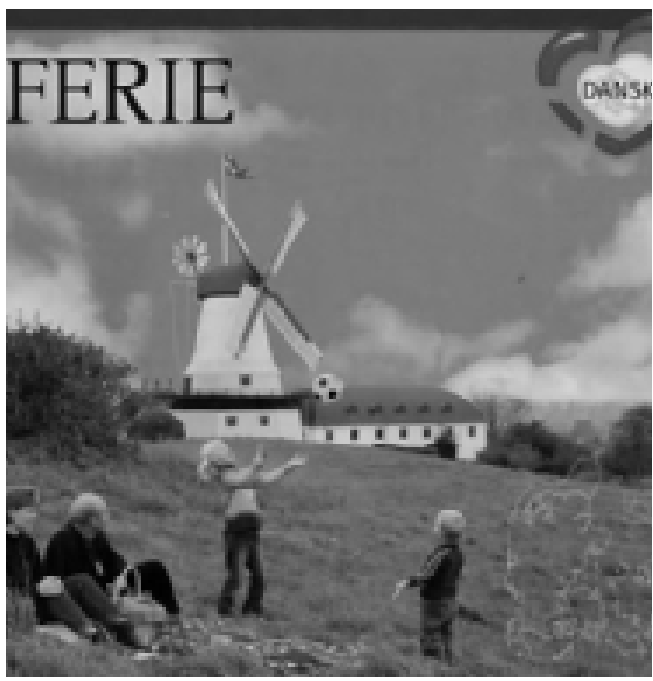

Dybbøls 12. metamorfose: Dybbøls vardi som turistattraktion forsøges styrket, og i trad hermed bruges Dybbøl Molle som national kitsch på den lokale turistbrochure $i$ 2005. Foto Museum Sønderjylland-Sønderborg Slot.

tryk for, at danskerne nu var kommet ud af skyggen af 1864, og dette blev kædet sammen med den aktivistiske danske udenrigspolitik siden begyndelsen af $1990{ }^{\prime}$ erne. $^{30}$

\section{DYBBØL SOM KANONISERET DANSK KULTUR-} ARV

Tre centrale begreber ligger bag denne analyse af skiftende tiders brug og iscenesættelse af lokaliteten Dybbøl: identitet, kulturarv og kanon, og det kan derfor være nyttigt kort at præsentere og præcisere dem.

Identiteter er forestillinger og følelser, der skabes og udvikles under opvæksten og ændres gennem livet som følge af de påvirkninger og de udfordringer, man møder. Vi har alle en mangfoldighed af identiteter, og det er vores særlige kombination af identiteter, der 
70 kendetegner os i forhold til andre. Identitetsfølelse og forskelstænkning er nært forbundet med hinanden. Når man føler sig i særlig samhørighed med noget eller nogen, er der uundgåeligt andet og andre, som man føler sig mindre forbundet med. Inkluderinger og ekskluderinger indgår derfor implicit $\mathrm{i}$ identitetsdannelsen. Selvom der er mange slags identiteter, så er den nationale identitet i en særlig klasse, da den kan sameksistere med næsten alle andre identiteter. Den rummer forestillingen om et særligt fællesskab mellem borgerne i en stat på trods af kulturelle, politiske og $ø$ konomiske forskelle.

Kulturarv er et ord, der har fået en markant stigende anvendelse på dansk gennem 1990 'erne. ${ }^{31}$ Det fremstår som et neutralt beskrivende ord uden politiske implikationer, men i begrebet ligger der en forestilling om en klart defineret kultur, der kan nedarves eller videregives fra generation til generation. I den store danske tekstkorpus 2000 kan man undersøge ord i naboskabet til kulturarv, og de afspejler de betydningsmæssige sammenhænge, som kulturarv optræder i. Blandt de hyppigst tilgrænsende ord er: 'kristne', 'græske', 'beskytte', 'europæiske', 'vor', 'bevare', 'beskytte', 'danske', 'nationale' og 'fælles'. ${ }^{32}$ I kulturarvsbegrebet indgår der således forestillinger om essentielle værdier og kontinuitet, og det er knyttet til territorier og folkegrupper.

Kanon er et ord med mange betydninger, men i en kulturarvssammenhæng betyder det rettesnor eller normsættende forbillede. ${ }^{33} \mathrm{Be}$ grebet kendes fra antikken og blev relanceret af den amerikanske litteraturkritiker Harold Bloom i 1994 som modreaktion på globalisering, relativisme og kritik af den vestlige verdens værdier. ${ }^{34}$ Et ti år senere, i 2004, søsatte den danske regering sit første kanonprojekt om litteratur, og det er hurtigt blevet efter- fulgt af en kulturkanon, en historiekanon og en demokratikanon.

I det kulturbegreb, hvori den nationale identitet indgår, er der også en stedlig dimension, idet kulturer antages at have velafgrænsede geografiske områder med kulturel homogenitet og monokulturalitet. De talrige forvandlinger af Dybbøl afspejler forskellige nationsprojekter: først det nationalliberale Danmarktil-Ejderen-projekt, dernæst det tyske nationsprojekt og efter 1920 forskellige varianter over det danske nationalstatsprojekt. I takt med nationalismens genopliven i Europa siden midten af 1980'erne er der sket en dansk reterritorialisering af Dybbøl med en stærk øget formidling af området. At globaliseringen medfører en stigende trang til at fastholde velkendte positioner og tilhørsforhold, kan virke som et paradoks, men det er et globalt fænomen, som fremhævet af Anne Krestina Povlsen i en artikel om kulturarv i kulturteoretisk perspektiv. ${ }^{35}$ På Dybbøl kommer behovet for at markere tilhørsforhold blandt andet til udtryk i en stærkt øget flagning. Frem til 1990 vajede der et dannebrog på Dybbøl Banke. I 2008 er der i dagtimerne sædvanligvis fire dannebrog.

Formålet med opførelsen af Historiecenteret i 1992 var dels at skabe en turistattraktion, dels - med daværende centerleder Hans Ole Hansens ord - være med til at bære vort lands historier og historie ind i det 21. århundrede og tydeliggøre den danske identitet. ${ }^{36}$ Dette udtryk kom straks til at fænge i dagspressens omtale af stedet. JydskeVestkysten bragte således en helsides artikel under overskriften "Identiteten ligger i Dybbøl". ${ }^{37}$ Udsagn af denne art hviler på en forestilling om, at 1864-krigen var et udtryk for den danske nations nødvendige selvforsvar og hærens heroiske indsats. Det er ikke identitetsopbyggende i 
at fastholde viden om, at krigen kom som følge af rystende naivitet, manglende realitetssans og foruroligende inkompetence hos de ansvarlige danske politikere, og at den danske hær var på bristepunktet på stormdagen. ${ }^{38}$

Disse kendsgerninger bør imidlertid inddrages, hvis man skal tegne et dækkende billede af denne krig. Men et kulturarvssted som Dybbøl indeholder kun den forenklede del af historien, som en bestemt tidsperiode kan identificere sig med. Dybbøl er blevet et symbol på dansk identitet $i$ en sådan grad, at undervisningsminister Bertil Haarder i 1986 kunne fremhæve kampen på Dybbøl som et ufravigeligt tema $\mathrm{i}$ en historieundervisning båret af kvalitetskrav. ${ }^{39}$ I tråd hermed er "Kampen ved Dybbøl" blevet udpeget i 2006 af et ministerielt udvalg som en af de 29 væsentlige begivenheder i den nye danske historiekanon for folkeskolen..$^{40}$

Kanoniseringer er ikke blot efterrationaliserende, men også foreskrivende - de sammenfatter ikke blot historien, men fortolker den også. På tilsvarende vis tjener den kanoniseringsbølge, vi oplever i øjeblikket, ikke kun til at udpege betydning og mening, men er $\mathrm{i}$ et vist omfang også med til at skabe dem. Hvad enten det drejer sig om Dybbøl eller andre kanoniserede begivenheder eller steder, er det af afgørende betydning at inddrage hele historien på godt og ondt og ikke kun den tilsyneladende glorværdige del. Det er også vigtigt at have for øje, at den kulturarv, der knyttes til en bestemt lokalitet, kan være af meget forskellig art. Det er som nævnt ikke blot danskere, tyskere, sønderjyder og hjemmetyskere, der bruger og fortolker Dybbøl på forskellig vis - det gør også mænd og kvinder, børn og voksne og alle mulige andre kategorier, som folk kan inddeles i.

Kulturarven er ikke en gave, vi har fået overdraget af forrige generationer. Det er først og fremmest en konstruktion med inkluderinger og ekskluderinger, og dens aktuelle udgave afhænger helt af, hvem der tager del i udvælgelsesprocesserne, der fremtræder som erindringsprocesser. Derfor er det vigtigt at afdxkke og analysere alle omdannelser og forvandlinger, fordi de afspejler, at identiteter og historiefortolkninger ikke blot er historieskabte, men også historieskabende. De dynamiske og omvekslende kulturarvs-tilskrivninger på Dybbøl afspejler dette klart. ${ }^{41}$

\section{NOTER}

1. Dybbøl og flere andre betydningsladede steder er beskrevet i Inge. Adriansen: Nationale symboler $i$ Det Danske Rige 1830-2000, bd. 2. København 2003.

2. www.statsamt.dk.

3. Peter Dragsbo: Dybbøl. Et erindringssted skrifter driftsherre. I: Journalen 1:2004, s. 26-30.

4. Det følgende afsnit om de 12 forvandlinger bygger især på Inge Adriansen: Dybbøl - et dansk og tysk nationalt symbol. I: Sønderjyske Arbøger 1992, s. 249-290; Inge Adriansen: Dybbol Mølle - Monument og Museum. 1997; Inge Adriansen: Dybbøl Bjerg og Skanser - et militært og civilt kulturlandskab. I: Nordisk Bygd, 12, 1999, s. 4555.

5. Dybbøl Sogns Historie, 1976, s. 348-354.

6. Ibid s. $363 \mathrm{f}$.

7. Johannes Nielsen: $1864-$ Da Europa gik af lave. Odense 1987, s. 70.

8. Ibid s. 228-265.

9. Ole Andersen: Festung Sonderburg-Düppel. Sønderborg 1993.

10. Inge Adriansen: Dybbol Mølle - Monument og Museum. Sønderborg 1997.

11. Holger Drachmann: Derovre fra Gransen. Her ef- 
ter Genforeningsudgaven 1919, s. 65-66.

12. Inge Adriansen: Nationale symboler $i$ Det Danske Rige, bd. 2. København 2003, s. 249-253.

13. Sonderburger Zeitung 29..-30. juni 1914.

14. Robert Ludvigsen: En Konges Ridt. København 1920, s. 58-60.

15. Lars H. Bak: Tyske sejrsmonumenter på danske hænder. I: Sønderjyske Arbøger, 2003, s. 12-18.

16. Det planlagte monument over Grundtvig blev til en kirke. Vedr. planerne om at placere den på Dybbøl Banke se Thomas Bo Jensen: P.V. JensenKlint. Kunstakademiets Arkitektskole 2006.

17. Inge Adriansen 2003, s. 291-295.

18. Se tegning af mødepladsen i Sven-Ingvar Anderson: C. Th. Sørensen og det skønne. I: Jens Schjerup Hansen (red.): Det gode, det skønne eller det baredygtige? 1994, s. 52.

19. Lars Bak 2003, s. 36 .

20. Talen blev refereret i dagbladene i de to følgende dage, men er ikke publiceret.

21. Björn Hettne, Sverker Sörlin og Uffe Østergård: Den globala nationalismen: Nationalstatens historia och framtid. Stockholm 1998, s. 7-8.

22. Ved oprettelsen af FN i 1945 var der 45 medlemmer. I 1985 ca. 150 og o. år 2000 næsten 200 medlemmer.

23. En donation fra Aage V. Jensens Fonde muliggjorde selve byggeriet og de offentlige kasser finansierede vejanlæg, parkeringspladser mv. Til konkurrencen indkom 192 forslag, der alle blev udstillet på Museet på Sønderborg Slot december-januar 1989-1990.

24. JydskeVestkysten 3. april 1991, 2. sek, Sønderborg-udgaven.

25. Dansk Folkeblad nr. 2 og 3, 1999.

26. Anette Warring: Historie, magt og identitet. Grundlovsfejringer gennem 150 år. Magtudredningen. Århus 2004, s. 206-208.

27. René Rasmussen; Slaget på Dybbøl Banke. En øjenvidneskildring af kampen om Historiecenter Dybbøl Bankes udvidelsesplaner. I: Fortid og Nu- tid, 2000, s.171-198.

28. Thue Damgaard Kjærhus: Retten til vor historie - Dybbøl set i lyset af videnssamfundet og det regionale perspektiv. I: Peter Dragsbo og Inge Adriansen (red.): Sønderjysk Kulturarv. Sønderjyske Museer 2003-2004, s. 92-97. Bjarke Larsen: De uforsonlige sønderjyder eller: Hvorfor er det så svært at 18. april som en mindedag i et moderne Europa. Smstd, s. 98-103.

29. http://www.1864.dk/.

30. Bertel Haarders tale er i arkivet på Sønderborg Slot.

31. Jf. Det Danske Sprog- og Litteraturselskab, Tekstkorpus 2000, der belyser det danske sprog omkring årtusindskiftet.

32. http://korpus.dsl.dk/korpus2000/php. Fra 1990 til år 2000 var der dukket to nye nabo-ord op: elektroniske kulturarv og verdens- kulturarv.

33. Jes Wienberg: Kanon, mindesmærker og oldtidsfund. I: Lars-Eric Jönsson m.fl.: Kanon och kulturarv. Historia och samtid i Danmark och Sverige. Göteborg \& Stockholm 2008, s. 37f.

34. Harold Bloom: The Western Kanon. The Books and School of the Ages. New York, San Diego \& London 1994.

35. Anne Krestina Povlsen: Kulturarv i kulturteoretisk perspektiv. I: Lars-Eric Jönsson m.fl.: Kanon och kulturarv. Historia och samtid i Danmark och Sverige. Göteborg \& Stockholm 2008, s. 257.

36. Hans Ole Hansen: Historiecenter Dybbøl Banke - et historiens fortællehus I: Sønderjysk Månedsskrift 1992, s. 148.

37. JydskeVestkysten 28.01.1992

38. K.V. Nielsen i Militært Tidsskrift 1987, s. 194. I Johannes Nielsen: 1864 - Da Europa gik af lave. 1987, s. 247- 248.

39. Se debat herom mellem Bertel Haarder og Karl Brøcher i tidsskriftet Folkeskolen 1986, s.17741775 og 1959.

40. Rapport fra Udvalget til styrkelse af historie i Folkeskolen. Undervisningsministeriet juni 2006. 
41. Hovedparten af denne artikel har været trykt på tysk i Inge Adriansen: Die 12 Metamorphosen von Düppel - eine Kulturlandschaft im Dienst der Erinnerungspolitik. I: Silke Göttsch \& Kai Detlev Sievers (Hg.): Kieler Blätter für Volkskunde. Kiel 2007, s. 23-50.

*Inge Adriansen, adjungeret professor i kulturhistorie ved Syddansk Universitet, museumsinspektør ved Museum Sønderjylland - Sønderborg Slot

Address: Sønderborg Slot, Sønderbro 1, 6400 Sønderborg

E-mail: inge.adriansen@museum-sonderjylland.dk 